\title{
Supporting Information for \\ Recent Trends in Water Use and Production for \\ California Oil Production
}

Kate Tiedeman,,,++ Sonia Yeh, $\dagger, \S$ Bridget R. Scanlon, // Jacob Teter, $\dagger, \perp$ and Gouri Shankar Mishra $†, \#$

† Institute of Transportation Studies, University of California, Davis, Davis, California 95616, United States

‡ Graduate Group in Ecology, University of California, Davis, Davis, California 95616, United States

$\S$ Department of Energy and Environment, Chalmers University of Technology, Gothenburg, Sweden 41273

॥Bureau of Economic Geology, Jackson School of Geosciences, University of Texas at Austin, Austin, Texas 78713-8924, United States

$\perp$ International Energy Agency, Cedex 15 Paris, France 75739

\#Precourt Energy Efficiency Center, Stanford University, Stanford, California 94305 United States

* Corresponding author. One Shields Ave, Davis, CA 95616. Tel: (650) 465-4181. Email:

kmtiedeman@ucdavis.edu.

\section{Pages}

\section{Figures}

\section{Tables}

\section{Table of Contents:}

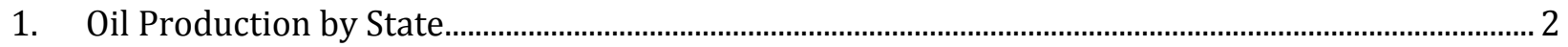

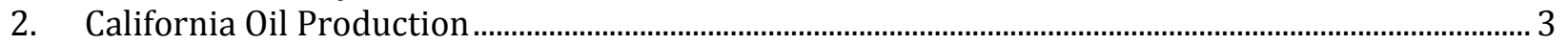

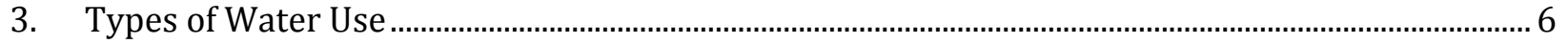

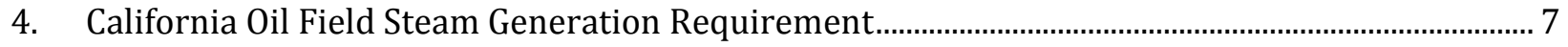

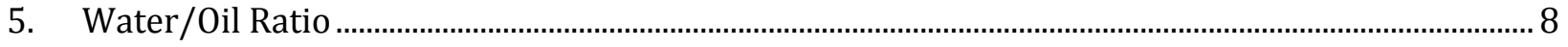

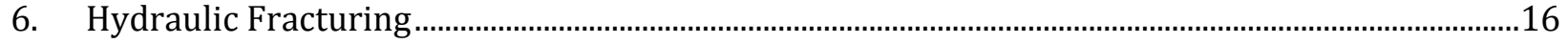

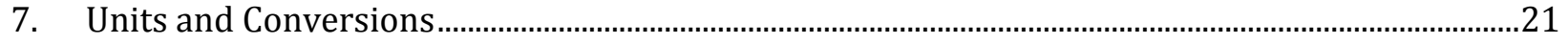

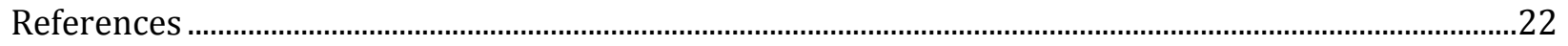




\section{Oil Production by State}

Table S1 gives a time series of oil production for the U.S.

Table S1. Top oil producing regions in the U.S. from 1985-2013, expressed in million barrels of oil. Based on EIA data. ${ }^{1}$

\begin{tabular}{|c|c|c|c|c|c|c|}
\hline Year & Texas & $\begin{array}{l}\text { Federal } \\
\text { Offshore-- } \\
\text { Gulf of } \\
\text { Mexico }\end{array}$ & $\begin{array}{l}\text { North } \\
\text { Dakota }\end{array}$ & California & Alaska & Oklahoma \\
\hline 1985 & 869 & 343 & 51 & 394 & 666 & 163 \\
\hline 1986 & 820 & 350 & 46 & 378 & 681 & 149 \\
\hline 1987 & 761 & 326 & 41 & 365 & 716 & 134 \\
\hline 1988 & 735 & 299 & 39 & 355 & 738 & 129 \\
\hline 1989 & 688 & 279 & 37 & 331 & 684 & 117 \\
\hline 1990 & 678 & 270 & 37 & 321 & 647 & 112 \\
\hline 1991 & 683 & 292 & 36 & 319 & 656 & 108 \\
\hline 1992 & 651 & 301 & 33 & 305 & 627 & 102 \\
\hline 1993 & 619 & 301 & 31 & 293 & 577 & 97 \\
\hline 1994 & 591 & 314 & 28 & 286 & 569 & 91 \\
\hline 1995 & 560 & 344 & 29 & 279 & 542 & 87 \\
\hline 1996 & 543 & 374 & 32 & 282 & 510 & 85 \\
\hline 1997 & 537 & 412 & 36 & 285 & 473 & 83 \\
\hline 1998 & 505 & 448 & 36 & 284 & 429 & 78 \\
\hline 1999 & 449 & 494 & 33 & 273 & 383 & 71 \\
\hline 2000 & 443 & 523 & 33 & 271 & 355 & 70 \\
\hline 2001 & 424 & 560 & 32 & 261 & 351 & 69 \\
\hline 2002 & 406 & 567 & 31 & 258 & 359 & 66 \\
\hline 2003 & 401 & 561 & 29 & 248 & 356 & 65 \\
\hline 2004 & 393 & 535 & 31 & 240 & 332 & 64 \\
\hline 2005 & 393 & 467 & 36 & 229 & 315 & 61 \\
\hline 2006 & 392 & 472 & 40 & 223 & 270 & 64 \\
\hline 2007 & 391 & 468 & 45 & 218 & 264 & 64 \\
\hline 2008 & 406 & 423 & 63 & 214 & 250 & 67 \\
\hline 2009 & 399 & 570 & 80 & 207 & 235 & 67 \\
\hline 2010 & 427 & 567 & 113 & 201 & 219 & 69 \\
\hline 2011 & 529 & 481 & 153 & 194 & 205 & 76 \\
\hline 2012 & 724 & 464 & 244 & 197 & 192 & 93 \\
\hline 2013 & 928 & 458 & 314 & 199 & 188 & 116 \\
\hline
\end{tabular}




\section{California Oil Production}

Figure S1 shows the historical oil production in billion liters of the top 20 producing oil fields in California. Midway-Sunset remained the highest producing field though the production has declined from 9 billion liters to 5 billion liters from 1999 to 2012.
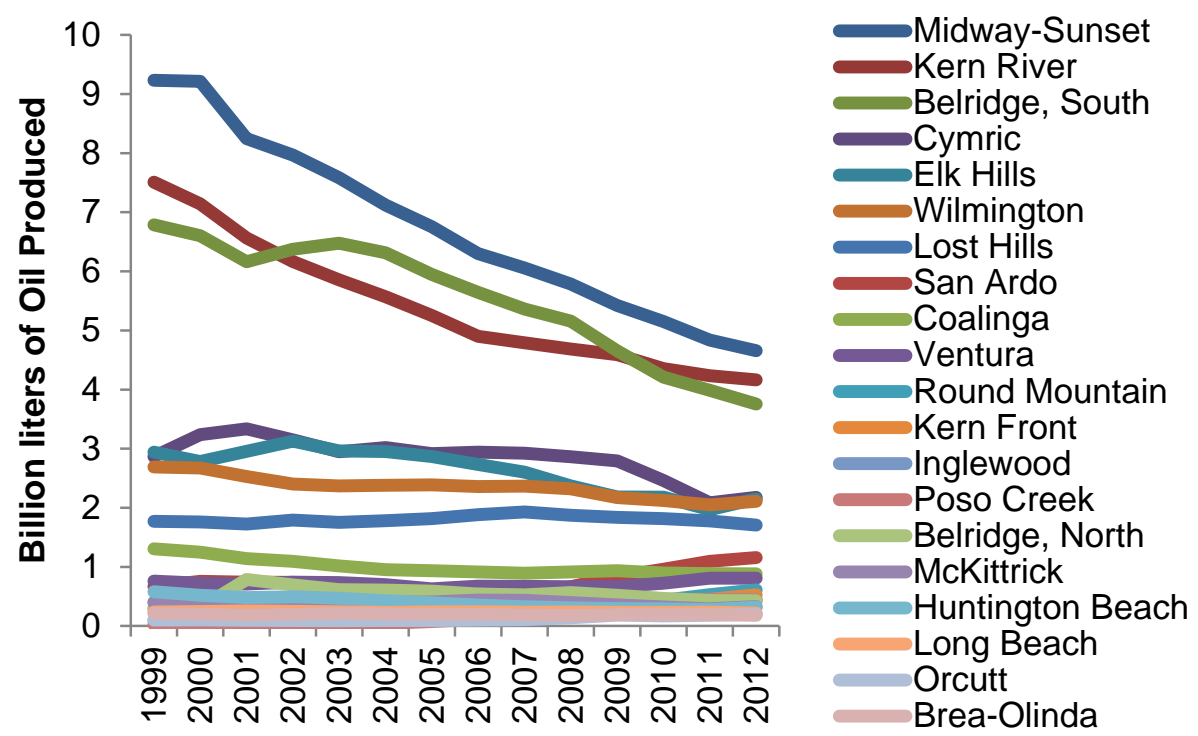

Figure S1. Oil produced (in billion liters per year) by top 20 producing fields in California.

In 2012, 18\% of oil and gas wells were located in fields that used exclusively secondary technology. These fields produced $26 \%$ of oil production in 2012 . A further $50 \%$ of wells were located in fields using exclusively tertiary technologies; these contributed 39\% of oil production. Finally, 27\% of wells were located in fields with "mixed" production, i.e. both secondary and tertiary technologies, and produced $30.4 \%$ of oil. This is a stark change from 1999 when only $8 \%$ of wells were classified as tertiary and produced only $8 \%$ of oil, and $71 \%$ of wells were on mixed fields, which produced $72 \%$ of total oil (Figure S2). 


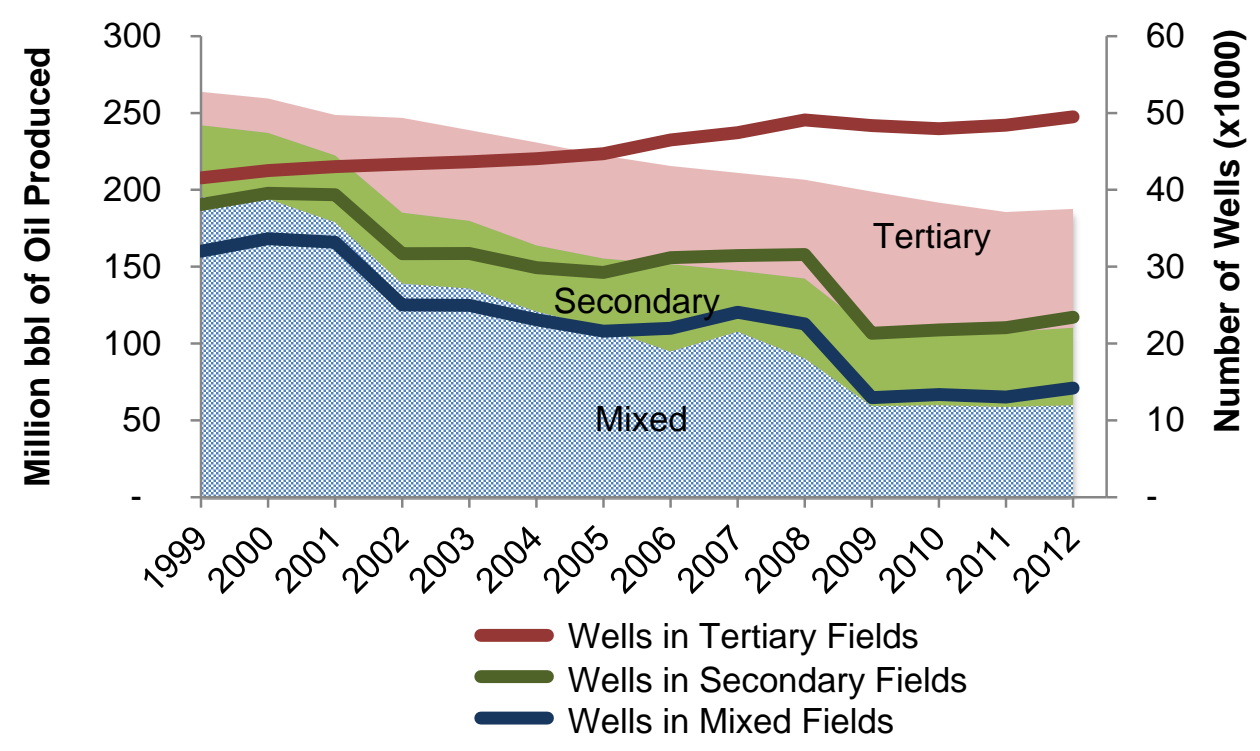

Figure S2. Oil produced and number of wells by production technology

The average annual output of wells decreased from 1999 to 2012 (Table S2) across conventional technology types. Between 1999 and 2012, the production weighted average age of oil producing wells increased from 19 to 23 years for secondary wells; from 9 to 16 years for tertiary wells, and decreased slightly from 13 to 12 years for wells on mixed fields.

Table S2. Oil output per year by production technology

\begin{tabular}{llrr}
\hline & Units & $\mathbf{1 9 9 9}$ & $\mathbf{2 0 1 2}$ \\
\hline Wells in secondary & Billion liters & 7.4 & 8.0 \\
extraction fields & Million barrels & 47 & 51 \\
Wells in tertiary & Billion liters & 3.5 & 12 \\
extraction fields & Million barrels & 22 & 77 \\
Wells in mixed & Billion liters & 31 & 10 \\
extraction fields & Million barrels & 200 & 60 \\
\hline
\end{tabular}


Thirteen fields switched production technologies during our study period, the production method is reported below (Table S3).

Table S3. Fields that changed production technology, 1999-2012.

\begin{tabular}{|l|l|l|l|l|l|l|l|l|l|l|l|l|l|l|}
\hline Field Name & $\mathbf{1 9 9 9}$ & $\mathbf{2 0 0 0}$ & $\mathbf{2 0 0 1}$ & $\mathbf{2 0 0 2}$ & $\mathbf{2 0 0 3}$ & $\mathbf{2 0 0 4}$ & $\mathbf{2 0 0 5}$ & $\mathbf{2 0 0 6}$ & $\mathbf{2 0 0 7}$ & $\mathbf{2 0 0 8}$ & $\mathbf{2 0 0 9}$ & $\mathbf{2 0 1 0}$ & $\mathbf{2 0 1 1}$ & $\mathbf{2 0 1 2}$ \\
\hline Belridge, North & $\mathrm{M}$ & $\mathrm{M}$ & $\mathrm{M}$ & $\mathrm{M}$ & $\mathrm{M}$ & $\mathrm{M}$ & $\mathrm{S}$ & $\mathrm{M}$ & $\mathrm{M}$ & $\mathrm{M}$ & $\mathrm{M}$ & $\mathrm{M}$ & $\mathrm{M}$ & $\mathrm{M}$ \\
\hline Buena Vista & & & & & & & & $\mathrm{S}$ & $\mathrm{M}$ & $\mathrm{M}$ & $\mathrm{M}$ & $\mathrm{M}$ & $\mathrm{S}$ & $\mathrm{S}$ \\
\hline Cat Canyon & $\mathrm{S}$ & $\mathrm{S}$ & $\mathrm{S}$ & $\mathrm{S}$ & $\mathrm{S}$ & $\mathrm{S}$ & $\mathrm{S}$ & $\mathrm{S}$ & $\mathrm{S}$ & $\mathrm{S}$ & $\mathrm{S}$ & $\mathrm{S}$ & $\mathrm{S}$ & $\mathrm{M}$ \\
\hline Edison & $\mathrm{T}$ & $\mathrm{M}$ & $\mathrm{M}$ & $\mathrm{M}$ & $\mathrm{M}$ & $\mathrm{M}$ & $\mathrm{T}$ & $\mathrm{T}$ & $\mathrm{T}$ & $\mathrm{T}$ & $\mathrm{T}$ & $\mathrm{T}$ & $\mathrm{T}$ & $\mathrm{T}$ \\
\hline Kern Front & $\mathrm{M}$ & $\mathrm{M}$ & $\mathrm{M}$ & $\mathrm{M}$ & $\mathrm{M}$ & $\mathrm{M}$ & $\mathrm{M}$ & $\mathrm{M}$ & $\mathrm{M}$ & $\mathrm{T}$ & $\mathrm{T}$ & $\mathrm{M}$ & $\mathrm{M}$ & $\mathrm{M}$ \\
\hline Kern River & $\mathrm{M}$ & $\mathrm{M}$ & $\mathrm{M}$ & $\mathrm{T}$ & $\mathrm{T}$ & $\mathrm{M}$ & $\mathrm{M}$ & $\mathrm{M}$ & $\mathrm{M}$ & $\mathrm{M}$ & $\mathrm{T}$ & $\mathrm{T}$ & $\mathrm{T}$ & $\mathrm{T}$ \\
\hline McKittrick & $\mathrm{M}$ & $\mathrm{M}$ & $\mathrm{T}$ & $\mathrm{M}$ & $\mathrm{M}$ & $\mathrm{M}$ & $\mathrm{T}$ & $\mathrm{T}$ & $\mathrm{T}$ & $\mathrm{T}$ & $\mathrm{T}$ & $\mathrm{T}$ & $\mathrm{T}$ & $\mathrm{T}$ \\
\hline Midway-Sunset & $\mathrm{M}$ & $\mathrm{M}$ & $\mathrm{M}$ & $\mathrm{M}$ & $\mathrm{M}$ & $\mathrm{T}$ & $\mathrm{T}$ & $\mathrm{T}$ & $\mathrm{T}$ & $\mathrm{T}$ & $\mathrm{T}$ & $\mathrm{T}$ & $\mathrm{T}$ & $\mathrm{T}$ \\
\hline Mount Poso & $\mathrm{T}$ & $\mathrm{T}$ & $\mathrm{T}$ & $\mathrm{T}$ & $\mathrm{T}$ & $\mathrm{T}$ & $\mathrm{T}$ & $\mathrm{T}$ & $\mathrm{T}$ & $\mathrm{T}$ & $\mathrm{T}$ & $\mathrm{T}$ & $\mathrm{T}$ & $\mathrm{M}$ \\
\hline Orcutt & $\mathrm{S}$ & $\mathrm{S}$ & $\mathrm{S}$ & $\mathrm{S}$ & $\mathrm{S}$ & $\mathrm{S}$ & $\mathrm{M}$ & $\mathrm{M}$ & $\mathrm{M}$ & $\mathrm{M}$ & $\mathrm{M}$ & $\mathrm{M}$ & $\mathrm{M}$ & $\mathrm{M}$ \\
\hline Placerita & $\mathrm{T}$ & $\mathrm{M}$ & $\mathrm{T}$ & $\mathrm{T}$ & $\mathrm{T}$ & $\mathrm{T}$ & $\mathrm{T}$ & $\mathrm{T}$ & $\mathrm{T}$ & $\mathrm{T}$ & $\mathrm{T}$ & $\mathrm{T}$ & $\mathrm{T}$ & $\mathrm{T}$ \\
\hline Poso Creek & $\mathrm{T}$ & $\mathrm{T}$ & $\mathrm{T}$ & $\mathrm{T}$ & $\mathrm{T}$ & $\mathrm{T}$ & $\mathrm{T}$ & $\mathrm{M}$ & $\mathrm{T}$ & $\mathrm{T}$ & $\mathrm{T}$ & $\mathrm{T}$ & $\mathrm{T}$ & $\mathrm{T}$ \\
\hline Wilmington & $\mathrm{M}$ & $\mathrm{M}$ & $\mathrm{M}$ & $\mathrm{M}$ & $\mathrm{M}$ & $\mathrm{M}$ & $\mathrm{M}$ & $\mathrm{S}$ & $\mathrm{M}$ & $\mathrm{S}$ & $\mathrm{S}$ & $\mathrm{S}$ & $\mathrm{S}$ & $\mathrm{S}$ \\
\hline
\end{tabular}

Note: "S”, “T” and "M” represents Secondary, Tertiary, and Mixed oil extraction. Changes in oil extraction method within a field has been highlighted. 


\section{Types of Water Use}

Our calculation of water use intensity distinguishes between water types, including produced water, fresh water, other, and wastewater. These categories are created based on sources of water reported in the DOGGR database, which differentiates water type in terms of water produced from oil and gas wells, water produced from water wells, domestic (municipal), ocean, industrial waste, domestic waste and any combination thereof (Table S4). In California, freshwater is used to describe water that contains 3,000 milligrams per liter $(\mathrm{mg} / \mathrm{L})$ or less total dissolved solids (TDS) ${ }^{2}$

Table S4. Water type and sources

\begin{tabular}{ll}
\hline Water Type (categories) & Water Source (DOGGR) \\
\hline Produced water injected & Produced from an oil and gas well \\
Fresh & Produced from a water well \\
& Domestic \\
Other & Ocean \\
& Other or combination of the above \\
Waste & Industrial waste \\
& Domestic waste \\
\hline
\end{tabular}




\section{California Oil Field Steam Generation Requirement}

Natural gas produced from an oil and gas well is captured on site, as flaring and venting of gas is prohibited in California. ${ }^{3}$ Flaring was estimated to occur in California until 2011. ${ }^{4}$ The produced natural gas is then marketed, or in the case of tertiary production, first used on site for steam production then unused gas is sold on the market. ${ }^{5}$ Both of these technologies use natural gas produced onsite or imported from elsewhere (if onsite production is insufficient) in cogeneration plants to create steam that is then used to extract crude oil. ${ }^{5}$ We first estimate the amount of natural gas produced by a field, then subtract the amount of estimated natural gas required to generate steam given oil production based on a generic efficiency rate of 0.435 . If there is any remaining gas after onsite use, we allocate total and net water use to oil and net gas produced (see Equation 3 in the main text) in Method 2. Table S5 gives the steam cogeneration capacity ${ }^{6}$ on tertiary fields with the gas required and estimated gas produced based on Equation 3 by field in 2012.

Table S5. Steam cogeneration capacity, estimated gas required and gas produced on tertiary fields 2012.

\begin{tabular}{lrrr}
\hline & $\begin{array}{c}\text { Steam Cogeneration } \\
\text { Capacity (thousand gal/hr) }\end{array}$ & $\begin{array}{c}\text { Gas Required } \\
\text { (MMCF) }\end{array}$ & $\begin{array}{c}\text { Gas Produced } \\
\text { (MMCF) }\end{array}$ \\
\hline Arroyo Grande & 325 & 164 & 0 \\
Cymric & 6,698 & 4,234 & 3,645 \\
Jasmin & 7,255 & $\mathrm{NA}$ & $\mathrm{NA}$ \\
Kern Front & 8,231 & 16,329 & $\mathrm{NA}$ \\
Kern River & 75,076 & 68,657 & 0 \\
Lost Hills & 1,651 & $\mathrm{NA}$ & $\mathrm{NA}$ \\
McKittrick & 3,753 & 1,832 & 2,512 \\
Midway-Sunset & 55,900 & 42,340 & 4,874 \\
Mount Poso & 625 & $\mathrm{NA}$ & $\mathrm{coal}$ \\
Orcutt & 0 & $\mathrm{NA}$ & $\mathrm{NA}$ \\
Coalinga & 12,934 & $\mathrm{NA}$ & $\mathrm{NA}$ \\
Poso Creek & 7,255 & $\mathrm{NA}$ & coal \\
Round Mountain & 0 & $\mathrm{NA}$ & $\mathrm{NA}$ \\
Placerita & 7,508 & 17,703 & 0 \\
Oxnard & 0 & $\mathrm{NA}$ & NA \\
San Ardo & 13,415 & $\mathrm{NA}$ & $\mathrm{NA}$ \\
\hline
\end{tabular}




\section{Water/Oil Ratio}

Table S6 gives the water/oil ratios by production type developed using Method 1: where oil produced is the denominator.

Table S6. Water/oil ratios (vol water/vol oil) by production technology (1999-2012) using Method 1 defined in Equation 2 of the main text.

\begin{tabular}{|c|c|c|c|c|c|c|c|c|c|c|c|c|c|c|c|}
\hline & $\begin{array}{l}\text { Production } \\
\text { Type }\end{array}$ & 1999 & 2000 & 2001 & 2002 & 2003 & 2004 & 2005 & 2006 & 2007 & 2008 & 2009 & 2010 & 2011 & 2012 \\
\hline \multirow[t]{4}{*}{ TWUI } & Secondary & 7.7 & 8.3 & 8.4 & 8.9 & 9.5 & 9.8 & 9.7 & 15.8 & 10.8 & 18.0 & 19.2 & 19.7 & 20.5 & 21.1 \\
\hline & Tertiary & 2.3 & 2.3 & 2.3 & 2.6 & 2.7 & 3.5 & 3.7 & 4.0 & 4.0 & 4.3 & 3.6 & 3.6 & 3.6 & 3.8 \\
\hline & Mixed & 5.0 & 5.2 & 5.0 & 6.5 & 7.0 & 7.4 & 8.4 & 5.5 & 9.6 & 6.6 & 9.0 & 8.6 & 8.0 & 8.1 \\
\hline & Total & 5.3 & 5.5 & 5.3 & 5.9 & 6.4 & 6.7 & 7.2 & 7.7 & 8.1 & 8.8 & 9.1 & 9.3 & 9.5 & 9.8 \\
\hline \multirow[t]{4}{*}{ FWUI } & Secondary & 0.9 & 1.1 & 1.0 & 0.8 & 0.6 & 0.6 & 0.6 & 0.5 & 0.6 & 0.5 & 0.4 & 0.4 & 0.5 & 0.4 \\
\hline & Tertiary & 0.0 & 0.0 & 0.0 & 0.0 & 0.0 & 0.1 & 0.2 & 0.3 & 0.4 & 0.6 & 0.5 & 0.5 & 0.6 & 0.8 \\
\hline & Mixed & 0.1 & 0.1 & 0.0 & 0.1 & 0.1 & 0.1 & 0.1 & 0.1 & 0.1 & 0.0 & 0.2 & 0.3 & 0.1 & 0.1 \\
\hline & Total & 0.2 & 0.2 & 0.2 & 0.2 & 0.2 & 0.2 & 0.2 & 0.2 & 0.3 & 0.3 & 0.4 & 0.4 & 0.4 & 0.5 \\
\hline \multirow[t]{4}{*}{ PWI } & Secondary & 8.1 & 8.6 & 9.0 & 9.7 & 10.6 & 11.2 & 11.0 & 16.6 & 13.0 & 19.0 & 20.3 & 21.0 & 22.1 & 22.5 \\
\hline & Tertiary & 7.8 & 6.5 & 6.5 & 7.4 & 8.1 & 5.9 & 6.3 & 6.1 & 7.4 & 8.9 & 9.4 & 9.3 & 10.9 & 11.4 \\
\hline & Mixed & 7.3 & 7.7 & 7.9 & 7.9 & 8.3 & 10.6 & 12.1 & 10.1 & 12.8 & 10.2 & 12.9 & 13.9 & 14.4 & 15.3 \\
\hline & Total & 7.5 & 7.8 & 7.9 & 8.1 & 8.7 & 9.3 & 10.1 & 10.6 & 11.2 & 12.0 & 13.1 & 13.7 & 15.0 & 15.6 \\
\hline \multirow[t]{4}{*}{ NWUI } & Secondary & 3.6 & 3.7 & 3.5 & 3.1 & 3.1 & 3.1 & 3.3 & 2.2 & 3.1 & 2.5 & 2.6 & 2.5 & 2.5 & 1.8 \\
\hline & Tertiary & 1.4 & 1.6 & 1.3 & 0.5 & 0.5 & 1.7 & 1.9 & 2.0 & 2.0 & 2.2 & 1.6 & 1.6 & 1.7 & 2.0 \\
\hline & Mixed & 2.1 & 2.1 & 2.1 & 2.9 & 3.0 & 2.7 & 2.7 & 3.5 & 3.3 & 4.2 & 6.2 & 5.9 & 5.2 & 5.1 \\
\hline & Total & 2.3 & 2.3 & 2.2 & 2.3 & 2.4 & 2.5 & 2.6 & 2.7 & 2.9 & 3.1 & 3.2 & 3.2 & 3.0 & 2.9 \\
\hline
\end{tabular}

Where TWUI is total water use Intensity, FWUI is freshwater use intensity, PWI is produced water intensity, and NWUI is net water use intensity 
Table S7 displays the same data, using Method 2, where water is allocated to oil and gas.

Table S7. Water/oil ratios (vol water/vol oil equivalent) by production type (1999-2012) using Method 2 defined in Equation 3 of the main text.

\begin{tabular}{|c|c|c|c|c|c|c|c|c|c|c|c|c|c|c|c|}
\hline & $\begin{array}{l}\text { Production } \\
\text { Type }\end{array}$ & 1999 & 2000 & 2001 & 2002 & 2003 & 2004 & 2005 & 2006 & 2007 & 2008 & 2009 & 2010 & 2011 & 2012 \\
\hline \multirow[t]{4}{*}{ TWUI } & Secondary & 4.8 & 5.1 & 5.3 & 5.7 & 6.1 & 6.2 & 6.2 & 10.7 & 6.8 & 12.6 & 13.6 & 13.4 & 14.5 & 14.8 \\
\hline & Tertiary & 2.3 & 2.3 & 2.3 & 2.6 & 2.7 & 3.5 & 3.7 & 4.0 & 4.0 & 4.3 & 3.6 & 3.6 & 3.6 & 3.7 \\
\hline & Mixed & 4.8 & 5.0 & 4.8 & 6.1 & 6.6 & 7.0 & 7.9 & 5.2 & 9.1 & 6.3 & 8.3 & 8.0 & 7.6 & 7.6 \\
\hline & Total & 4.6 & 4.8 & 4.7 & 5.2 & 5.6 & 5.9 & 6.3 & 6.7 & 7.1 & 7.7 & 8.1 & 8.1 & 8.4 & 8.6 \\
\hline \multirow[t]{4}{*}{ FWUI } & Secondary & 0.6 & 0.7 & 0.6 & 0.5 & 0.4 & 0.4 & 0.4 & 0.3 & 0.4 & 0.3 & 0.3 & 0.3 & 0.3 & 0.3 \\
\hline & Tertiary & 0.0 & 0.0 & 0.0 & 0.0 & 0.0 & 0.1 & 0.2 & 0.3 & 0.4 & 0.6 & 0.5 & 0.5 & 0.6 & 0.8 \\
\hline & Mixed & 0.1 & 0.1 & 0.0 & 0.1 & 0.1 & 0.1 & 0.1 & 0.1 & 0.1 & 0.0 & 0.1 & 0.3 & 0.1 & 0.1 \\
\hline & Total & 0.2 & 0.2 & 0.2 & 0.2 & 0.1 & 0.1 & 0.2 & 0.2 & 0.2 & 0.3 & 0.3 & 0.3 & 0.4 & 0.4 \\
\hline \multirow[t]{4}{*}{ PWI } & Secondary & 4.8 & 5.2 & 5.5 & 6.1 & 6.8 & 7.0 & 7.0 & 11.1 & 8.0 & 13.0 & 14.1 & 14.0 & 15.2 & 15.8 \\
\hline & Tertiary & 7.8 & 6.4 & 6.5 & 7.3 & 8.0 & 5.8 & 6.0 & 5.9 & 7.2 & 8.6 & 9.1 & 9.0 & 10.6 & 11.3 \\
\hline & Mixed & 7.0 & 7.4 & 7.5 & 7.4 & 7.9 & 9.9 & 11.4 & 9.5 & 12.0 & 9.6 & 11.8 & 12.8 & 13.4 & 14.4 \\
\hline & Total & 6.5 & 6.8 & 6.9 & 7.1 & 7.6 & 8.1 & 8.7 & 9.1 & 9.7 & 10.4 & 11.4 & 11.7 & 12.9 & 13.7 \\
\hline \multirow[t]{4}{*}{ NWUI } & Secondary & 2.3 & 2.3 & 2.2 & 2.0 & 2.0 & 2.0 & 2.1 & 1.5 & 2.0 & 1.7 & 1.8 & 1.7 & 1.7 & 1.3 \\
\hline & Tertiary & 1.4 & 1.6 & 1.3 & 0.5 & 0.5 & 1.7 & 1.9 & 2.0 & 2.0 & 2.2 & 1.6 & 1.6 & 1.8 & 2.0 \\
\hline & Mixed & 2.0 & 2.0 & 2.0 & 2.7 & 2.8 & 2.5 & 2.5 & 3.3 & 3.1 & 4.0 & 5.7 & 5.5 & 4.9 & 4.8 \\
\hline & Total & 2.1 & 2.0 & 2.0 & 2.0 & 2.1 & 2.2 & 2.2 & 2.4 & 2.5 & 2.8 & 2.9 & 2.8 & 2.7 & 2.6 \\
\hline
\end{tabular}


Table S8 shows the mean, median, and $95^{\text {th }}$ percentile of individual field-based water/oil ratio using Method 1 and Method 2 for 1999 and 2012.

Table S8. Water/oil ratios (vol water/vol oil equivalent) by production type (1999-2012) using Method 1 defined in Equation 1 and Method 2 defined in Equation 2 of the main text.

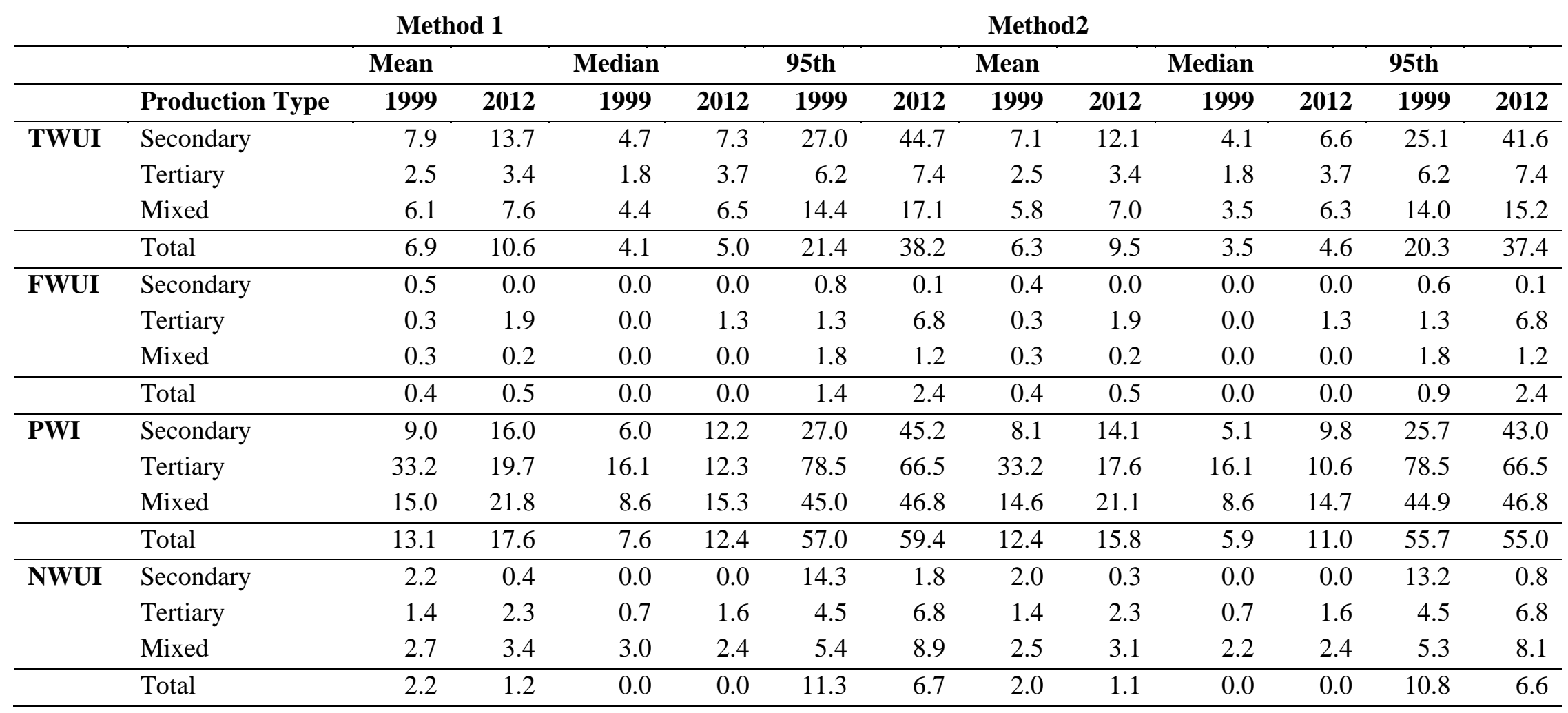


Table S9 summarizes WUI estimates from the literature for comparison. Of the documented technologies, primary recovery is typically the least water intensive; Gleick et al. (1994) estimate that primary recovery uses 0.21 liters $(\mathrm{L})$ of freshwater per $\mathrm{L}$ of crude oil recovered. This value is cited throughout recent literature with little further research or independent estimates. ${ }^{7-10}$ The WUI of secondary recovery, or water flooding, which represents the majority of U.S.

conventional oil recovery, varies by location and technology, but the most referenced point-value estimate of WUI is 8.6 liters of water per liter of oil recovered over the lifetime of a well. ., $^{\text {. }}$ The amount of injection water used for tertiary recovery or EOR is highly variable, and dependent on technology and location/geology. Water use intensity may be as low as $1.9 \mathrm{~L}$ water / L of oil recovered with "forward combustion" technology a process by which air is injected or air and water are co-injected into the reservoir. The oil is ignited to reduce viscosity, and is driven upwards by the combination of the gas drive from the combustion gases, a steam drive and a water drive. This process is also called fire flooding. Or the water intensity can be as high as $343 \mathrm{~L} / \mathrm{L}$ with "micellar polymer injection" technology, ${ }^{8,9}$ a process with four separate injection phases; a pre-flush, micro-emulsion, an injection of polymer solution to increase viscosity, and a final brine injection. ${ }^{12}$ Estimated WUI of $\mathrm{CO}_{2}$ injection technologies vary from 4.3 L/L (Barry 2007), $13 \mathrm{~L} / \mathrm{L}^{13}$ to $24.7 \mathrm{~L} / \mathrm{L}^{8}$, though the range typically cited in the literature is 8.7- 24.7 L/L of oil recovered. ${ }^{8-10,14}$ In California, steam flooding and cyclic steam are the only water injecting EOR technologies recorded. In California, the steam to oil ratio (SOR) has been estimated at 4.1-168 L/L for fields using steam flooding technology, to $1.1 \mathrm{~L} / \mathrm{L}-85 \mathrm{~L} / \mathrm{L}$ in cyclic steam fields in $2006^{5,15}$ for $\mathrm{CO}_{2}$ emission quantification purposes, but does not take water recycling into account.

Table S9. Water use intensity (WUI) of oil production reported in the literature

\begin{tabular}{lcll}
\hline Type of extraction & $\begin{array}{c}\text { WUI } \\
\text { (vol water/ } \\
\text { vol oil) }\end{array}$ & Source & Note \\
\hline $\begin{array}{l}\text { Primary } \\
\text { Secondary }\end{array}$ & 1.4 & Gleick (1994) & \\
Tertiary (EOR) & 8.6 & Bush \& Helander (1968) & \\
Steam & 5.4 & Gleick (1994) & Survey of 14 oil companies \\
$\mathrm{CO}_{2}$ & 13 & Royce (1984) & Shell's Denver City project \\
& 24.7 & Gleick (1994) & (1988-1998 average) \\
& 4.3 & Barry (2007) & \\
Caustic & & & \\
Forward combustion & 3.87 & Gleick (1994) & Not currently practiced in US \\
Other & 1.93 & Gleick (1994) & Gleick (1994) \\
Micellar polymer injection & 8.7 & Gleick (1994) &
\end{tabular}

Wu et al. (2009) took volumes of oil produced in individual Petroleum Administrative Defense Districts (PADD regions) by various technologies and WUI values in the literature (Table S9) 
and calculated the average WUI for the U.S. They then considered produced water volumes in each PADD region to derive the net consumptive water use for petroleum recovery in each PADD. The study calculated the production-weighted net water to oil ratio by subtracting produced water injected from total injected water, and dividing by total oil produced. The net water use intensity was estimated at $5.4 \mathrm{vol} / \mathrm{vol}$ for the PADD 5 region (where California is located).

The estimates for secondary production are based on data from Bush and Helander (1968), typically reported as a point estimate $(8.6 \mathrm{vol} / \mathrm{vol})$. The estimates of water use and oil produced are presented in Figure S3.

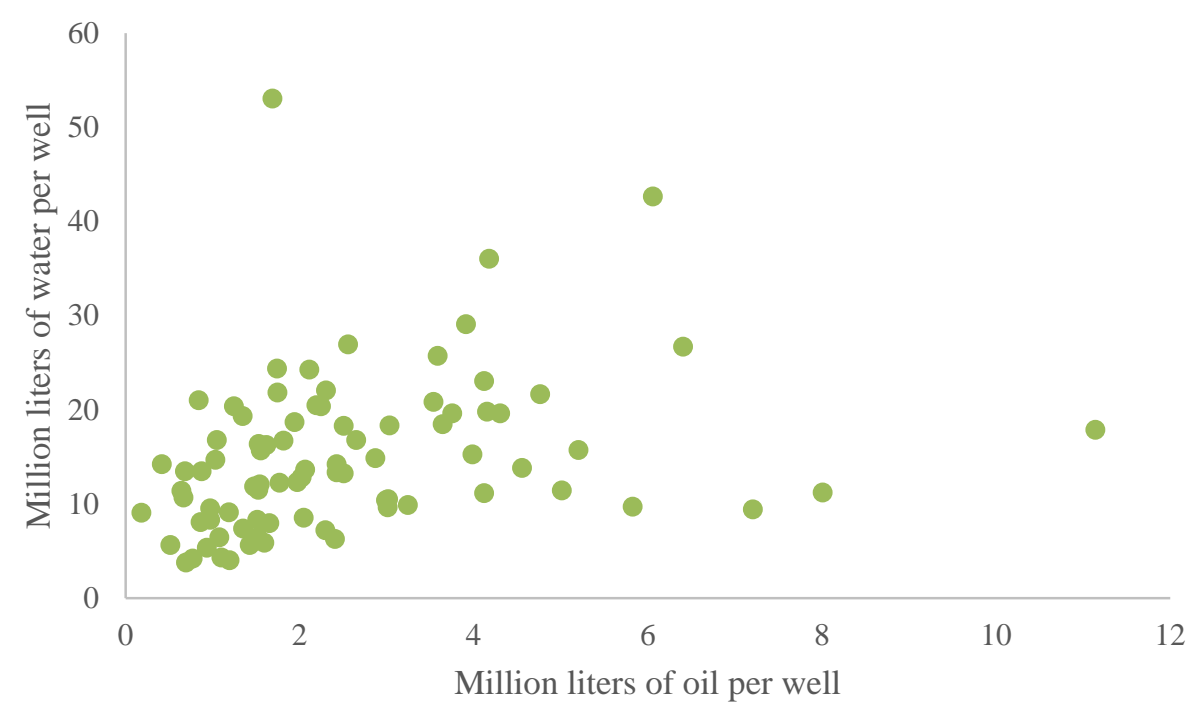

Figure S3. Oil produced (in million liters per year per well) and water use estimated in Bush and Helander (1968).

We estimated Net Water Use Intensity (NWUI) presented by water type (Figure S4), as well as the percent of produced water reinjected (Figure S5), calculated as the amount of produced water used in oil recovery divided by the total produced water. 
Secondary Production

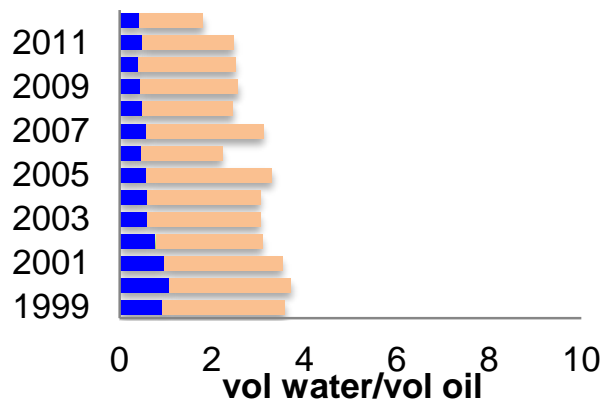

Mixed Production

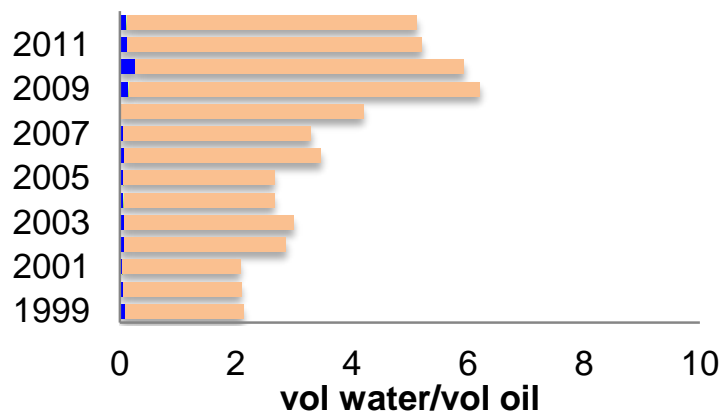

Tertiary Production

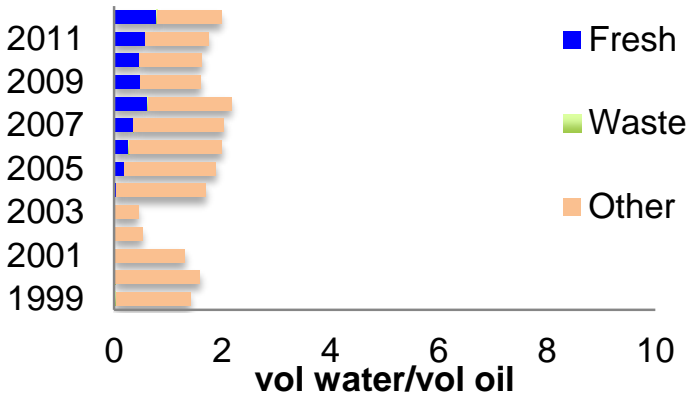

Total Production

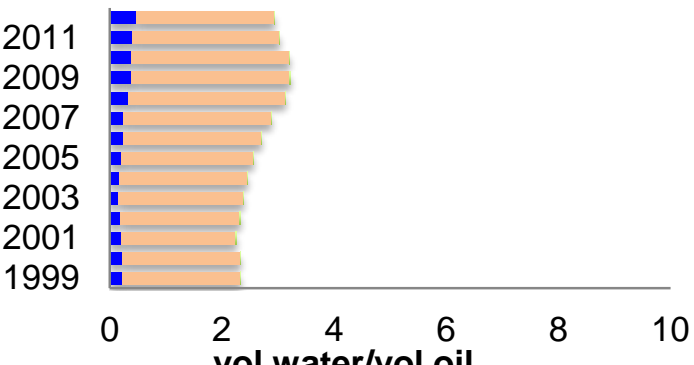

Figure S4. Net water use intensity (NWUI) by production type in California, 1999-2012. 

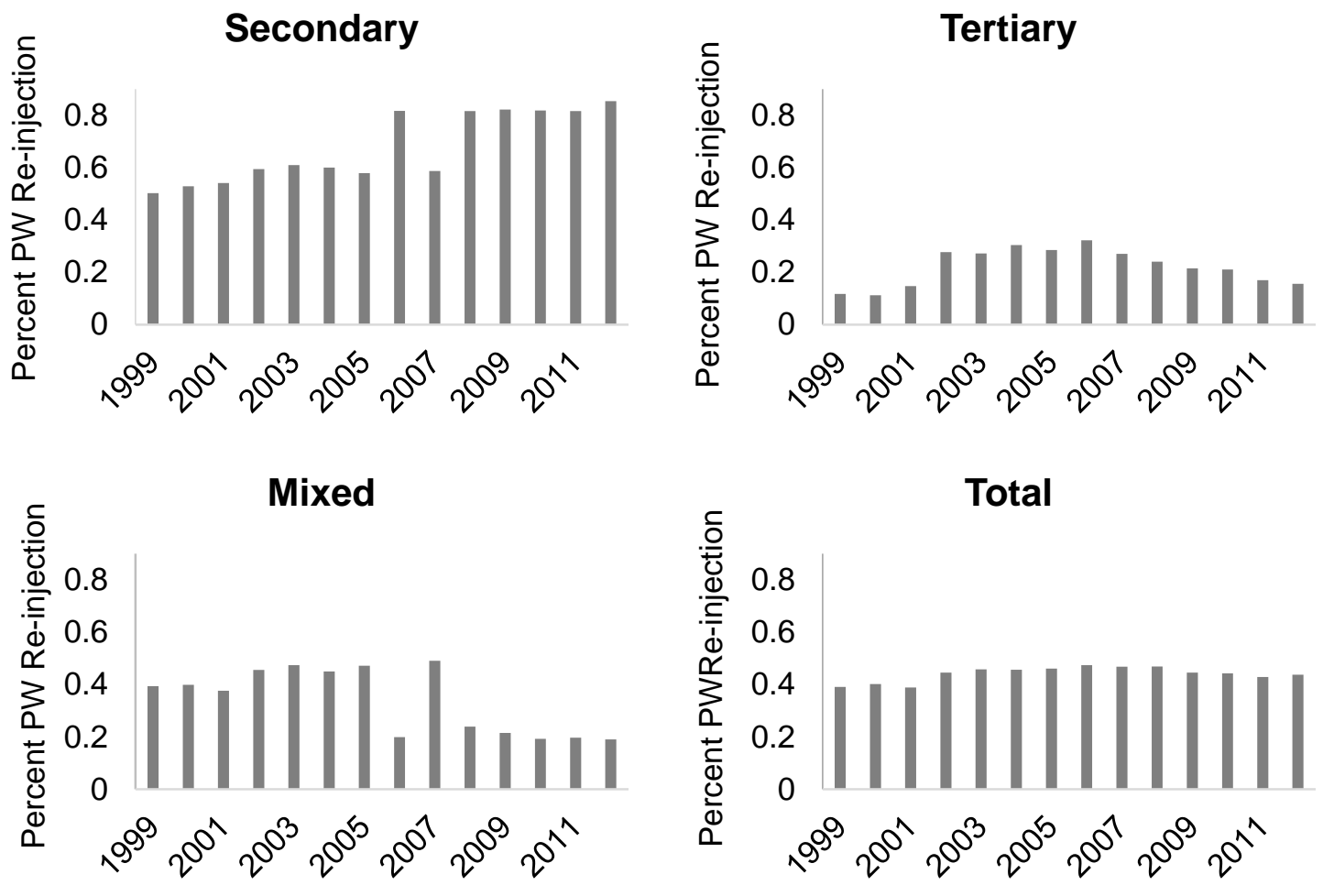

Figure S5. Percent produced water reinjection by production type in California, 1999-2012. 

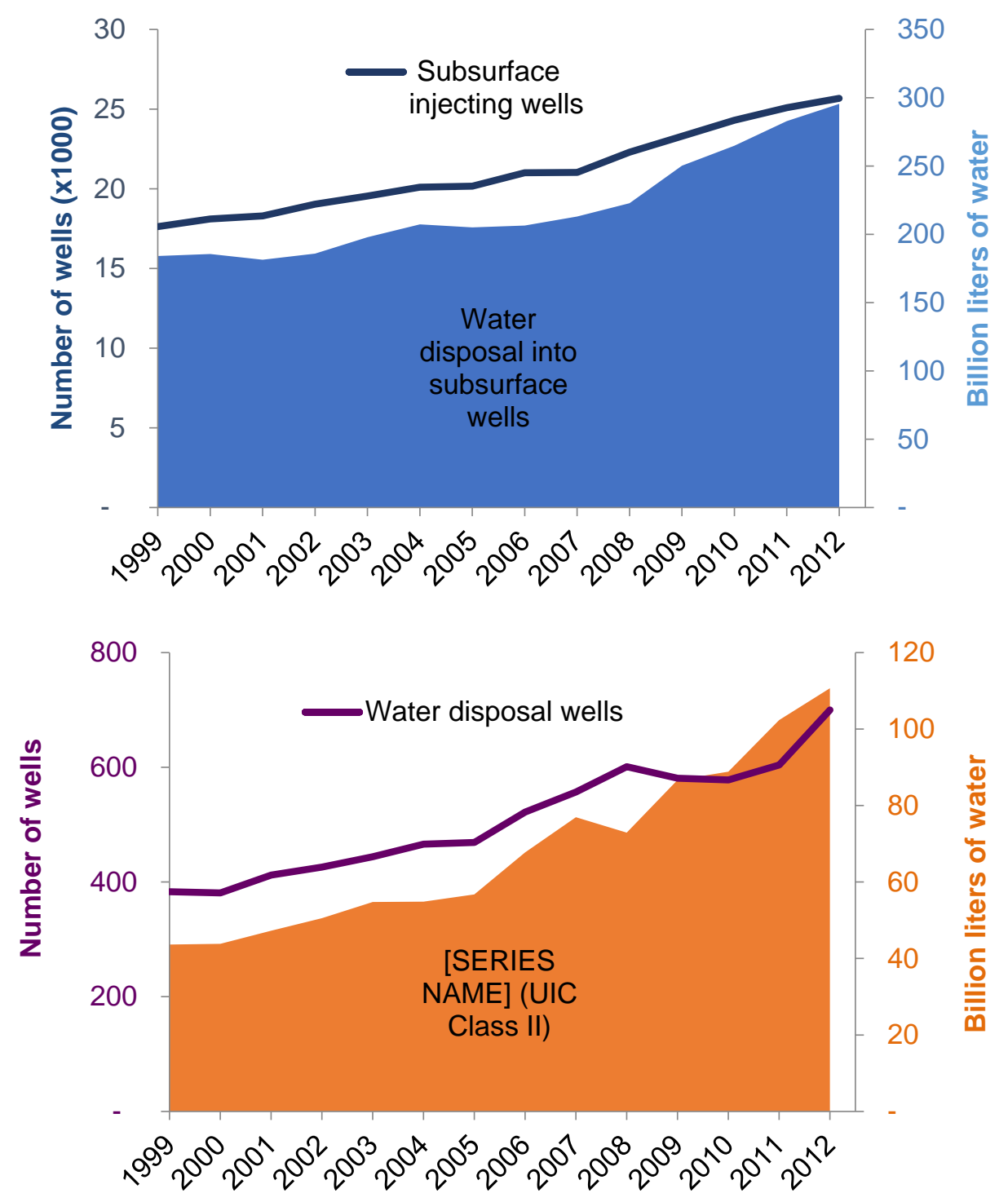

Figure S6. Number of subsurface injection wells (top) and water disposal wells (bottom) and total water injected, 1999-2012. 


\section{Hydraulic Fracturing}

Table S10 displays the number of wells using directional, horizontal, and vertical drilling, with the oil production use per well and the total oil production in million liters in 2012 and 2013.

Table S10. Hydraulic fracturing oil production per well per year, by hole direction, 2012-2013.

\begin{tabular}{|l|c|c|c|c|c|c|}
\hline \multicolumn{2}{|c|}{} & \multicolumn{3}{c|}{$\begin{array}{c}\text { Oil production (million liters) per } \\
\text { well per year }\end{array}$} & $\begin{array}{c}\text { Total oil } \\
\text { production } \\
\text { (million liters) }\end{array}$ \\
\hline Year & $\begin{array}{c}\text { Hole } \\
\text { direction }\end{array}$ & $\begin{array}{c}\text { \# of } \\
\text { wells }\end{array}$ & Median & Mean & $\begin{array}{c}95^{\text {th }} \\
\text { percentile }\end{array}$ & Total \\
\hline 2012 & Directional & 115 & 0.3 & 0.5 & 1.4 & 66 \\
\hline & Horizontal & 34 & 2.4 & 2.4 & 5.3 & 91 \\
\hline & Vertical & 152 & 0.4 & 0.7 & 2.4 & 111 \\
\hline & Total & 301 & 0.4 & 0.8 & 2.9 & 268 \\
\hline 2013 & Directional & 167 & 0.6 & 0.8 & 1.7 & 138 \\
\hline & Horizontal & 20 & 3.2 & 3.0 & 7.1 & 66 \\
\hline & Vertical & 157 & 0.7 & 0.8 & 1.8 & 130 \\
\hline & Total & 344 & 0.7 & 0.9 & 2.5 & 334 \\
\hline
\end{tabular}

Table S11 displays the number of wells using directional, horizontal, and vertical drilling, with the water use per well, water use intensity and flowback-produced water intensity, in volume of water per volume of oil extracted. 
Table S11. Hydraulic fracturing water use per well per year, water use and flowback-produced (FP) water ratios by hole direction, 20122013.

\begin{tabular}{|c|c|c|c|c|c|c|c|c|c|c|c|}
\hline \multirow{2}{*}{ Year } & \multirow[b]{2}{*}{$\begin{array}{l}\text { Hole } \\
\text { direction }\end{array}$} & \multirow[b]{2}{*}{$\begin{array}{l}\text { Number } \\
\text { of wells }\end{array}$} & \multicolumn{3}{|c|}{$\begin{array}{c}\text { Water use (million liters) per } \\
\text { well per year }\end{array}$} & \multicolumn{3}{|c|}{$\begin{array}{l}\text { Water use intensity (vol water } \\
\text { / vol oil) }\end{array}$} & \multicolumn{3}{|c|}{$\begin{array}{l}\text { Flowback-Produced water } \\
\text { intensity (vol water/vol oil) }\end{array}$} \\
\hline & & & Median & Mean & $\begin{array}{c}95^{\text {th }} \\
\text { percentile }\end{array}$ & Median & Mean & $\begin{array}{c}95^{\text {th }} \\
\text { percentile }\end{array}$ & Median & Mean & $\begin{array}{c}95^{\text {th }} \\
\text { percentile }\end{array}$ \\
\hline \multirow[t]{4}{*}{2012} & Directional & 115 & 0.30 & 0.44 & 1.11 & 0.85 & 3.1 & 10.9 & 6.9 & 13.8 & 66.9 \\
\hline & Horizontal & 34 & 1.40 & 1.85 & 4.13 & 0.64 & 3.2 & 8.7 & 3.1 & 6.3 & 25.3 \\
\hline & Vertical & 152 & 0.36 & 0.58 & 1.13 & 1.1 & 4.0 & 17.1 & 3.9 & 9.4 & 30.8 \\
\hline & Total & 301 & 0.35 & 0.67 & 1.95 & 1.0 & 3.5 & 14.6 & 4.8 & 10.8 & 40.7 \\
\hline \multirow[t]{4}{*}{2013} & Directional & 167 & 0.31 & 0.42 & 1.11 & 0.47 & 2.7 & 5.5 & 7.4 & 21.7 & 68.6 \\
\hline & Horizontal & 20 & 1.51 & 1.49 & 2.15 & 0.66 & 1.4 & 3.9 & 5.2 & 6.8 & 9.5 \\
\hline & Vertical & 157 & 0.29 & 0.45 & 1.05 & 0.5 & 2.3 & 2.8 & 4.6 & 11.2 & 35.6 \\
\hline & Total & 344 & 0.31 & 0.50 & 1.49 & 0.5 & 2.4 & 4.3 & 5.8 & 16 & 41.5 \\
\hline
\end{tabular}




\section{Calculation of Water Use Intensity for HF}

Table S12 below presents calculations of water use per well per year and water use intensity for oil-producing wells only and all wells (including non-producing).

Table S12. Hydraulic fracturing water use per well per year, and total WUI, 2012-2013.

\begin{tabular}{|l|l|r|r|r|r|r|}
\hline \multicolumn{2}{|l|}{} & \multicolumn{2}{|c|}{ Water use (million liters) per well } & \multicolumn{2}{|l|}{$\begin{array}{l}\text { Water use intensity (vol } \\
\text { water / vol oil) }\end{array}$} \\
\hline Year & Method & $\begin{array}{l}\text { Number of } \\
\text { wells }\end{array}$ & Median & Mean & $95^{\text {th }}$ percentile & \multicolumn{2}{|c|}{ Total } \\
\hline 2012 & $\begin{array}{l}\text { Oil-producing } \\
\text { wells only }\end{array}$ & 301 & 0.35 & 0.67 & 1.95 & 0.82 \\
\hline 2012 & All & 498 & 0.32 & 0.75 & 1.91 & 1.40 \\
\hline 2013 & $\begin{array}{l}\text { Oil-producing } \\
\text { wells only }\end{array}$ & 344 & 0.31 & 0.50 & 1.49 & 0.54 \\
\hline 2013 & All & 436 & 0.28 & 0.47 & 1.41 & 0.63 \\
\hline
\end{tabular}

Table S13 gives the number of unique wells using a treatment method as identified by FracFocus in 2012. Wells may use multiple chemicals that serve the functions listed below. Only seven, or two percent, of the wells in California reported using hydrochloric acid, or acid treatment to help dissolve minerals and initiate cracks in the rock, compared to 11,084 or 66 percent of hydraulic fracturing wells in the rest of the U.S. 13 percent of California wells used biocides and 99 percent of California hydraulic fracturing wells used gelling agents such as Methanol, shown to cause neurological damage and dermatitis in the case of acute toxicity. ${ }^{16,17}$ In the rest of the U.S. 60 percent of hydraulic fracturing wells used biocides, and 96 percent of wells used chemicals identified as gelling agents by FracFocus.

Table S13. Percent of hydraulic fracturing wells using chemical products, CA and US: 2012

\begin{tabular}{lcc}
\hline Product Function & California & Rest of U.S. \\
\hline Acid & $2 \%$ & $66 \%$ \\
Biocide & $13 \%$ & $60 \%$ \\
Breaker & $86 \%$ & $70 \%$ \\
Clay Stabilizer & $6 \%$ & $59 \%$ \\
Corrosion Inhibitor & $28 \%$ & $84 \%$ \\
Crosslinker & $100 \%$ & $95 \%$ \\
Friction Reducer & $99 \%$ & $93 \%$ \\
Gelling Agent & $99 \%$ & $96 \%$ \\
Iron Control & $16 \%$ & $55 \%$ \\
Non-Emulsifier & $81 \%$ & $67 \%$ \\
pH Adjusting Agent & $99 \%$ & $71 \%$ \\
Scale Inhibitor & $100 \%$ & $13 \%$ \\
Surfactant & $30 \%$ & $91 \%$ \\
\hline
\end{tabular}


Figure S7 presents the location of oil fields by type of production method (in 2012) and the location of HF wells in California in 2012 and 2013.

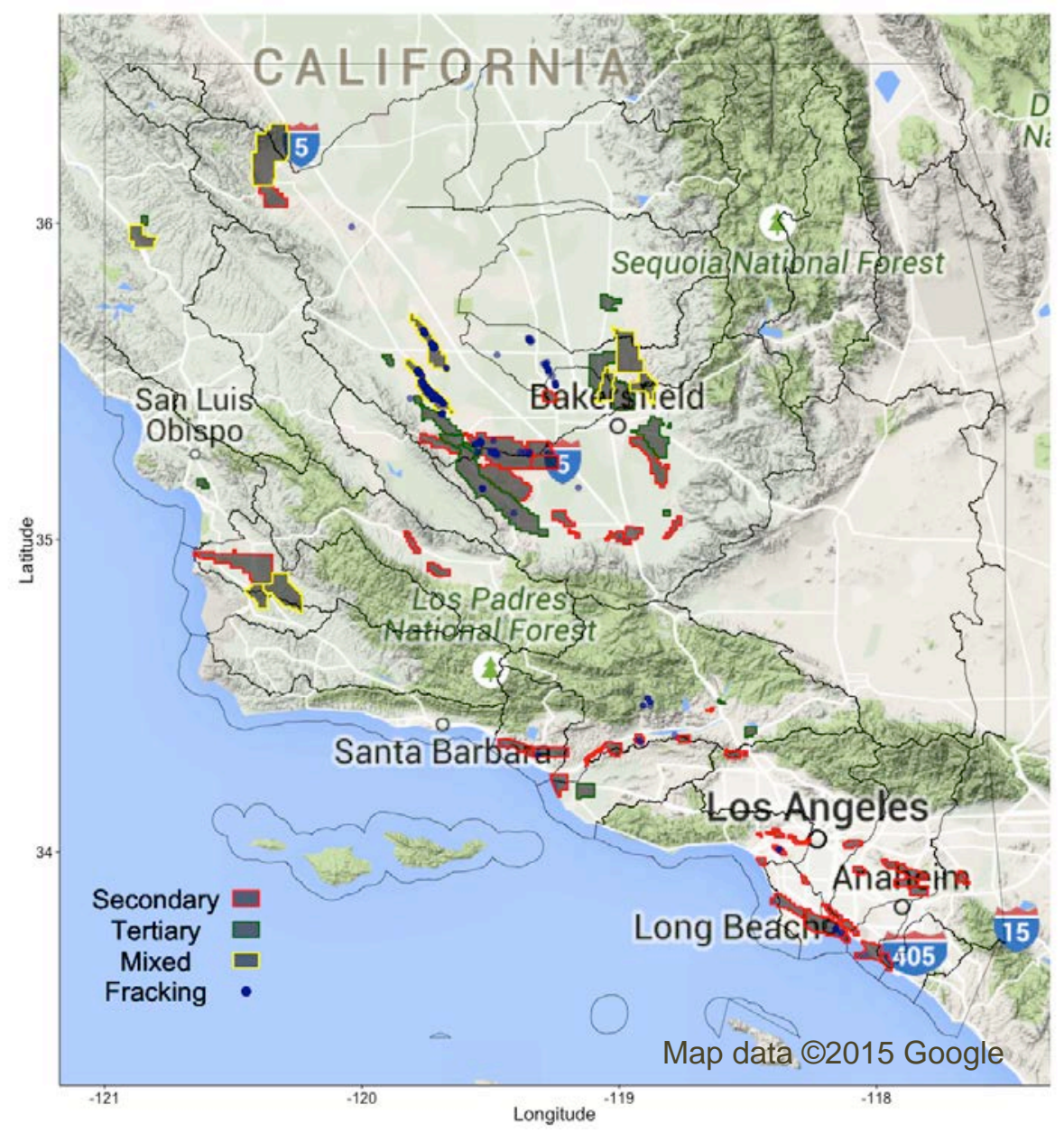

Figure S7. Oil Fields, Hydraulic Fracturing wells by type 
We compared data sources and found that $87 \%$ of the water volumes reported by FracFocus and IHS databases agreed to $\pm 10 \%$ (Figure S8).

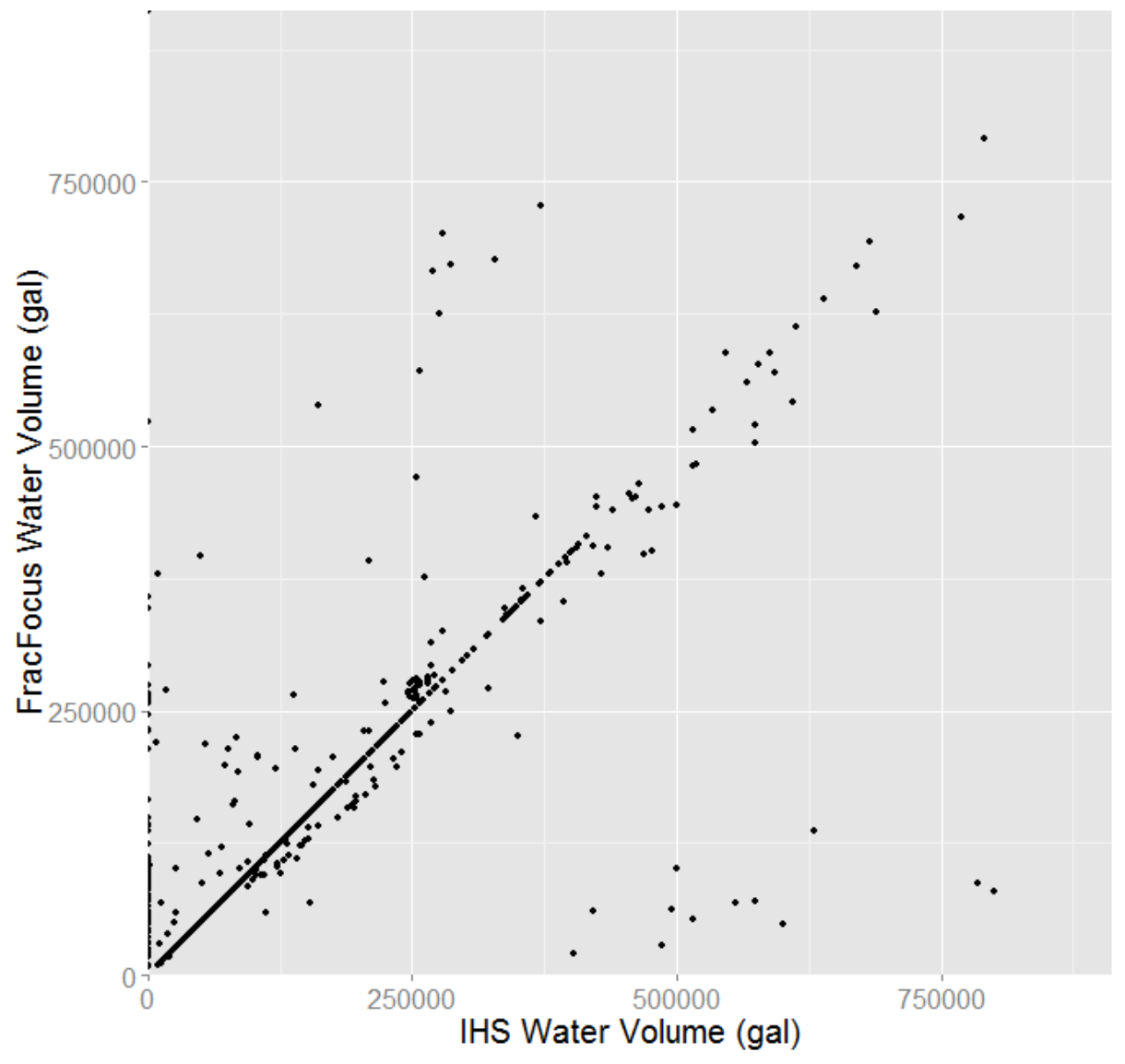

Figure S8. Comparison of Water volumes (in gallons) reported by FracFocus and IHS databases. 
In a comparison of DOGGR database and HIS database reported oil production, we found that $99 \%$ of wells agreed to $\pm 10 \%$ (Figure S9).

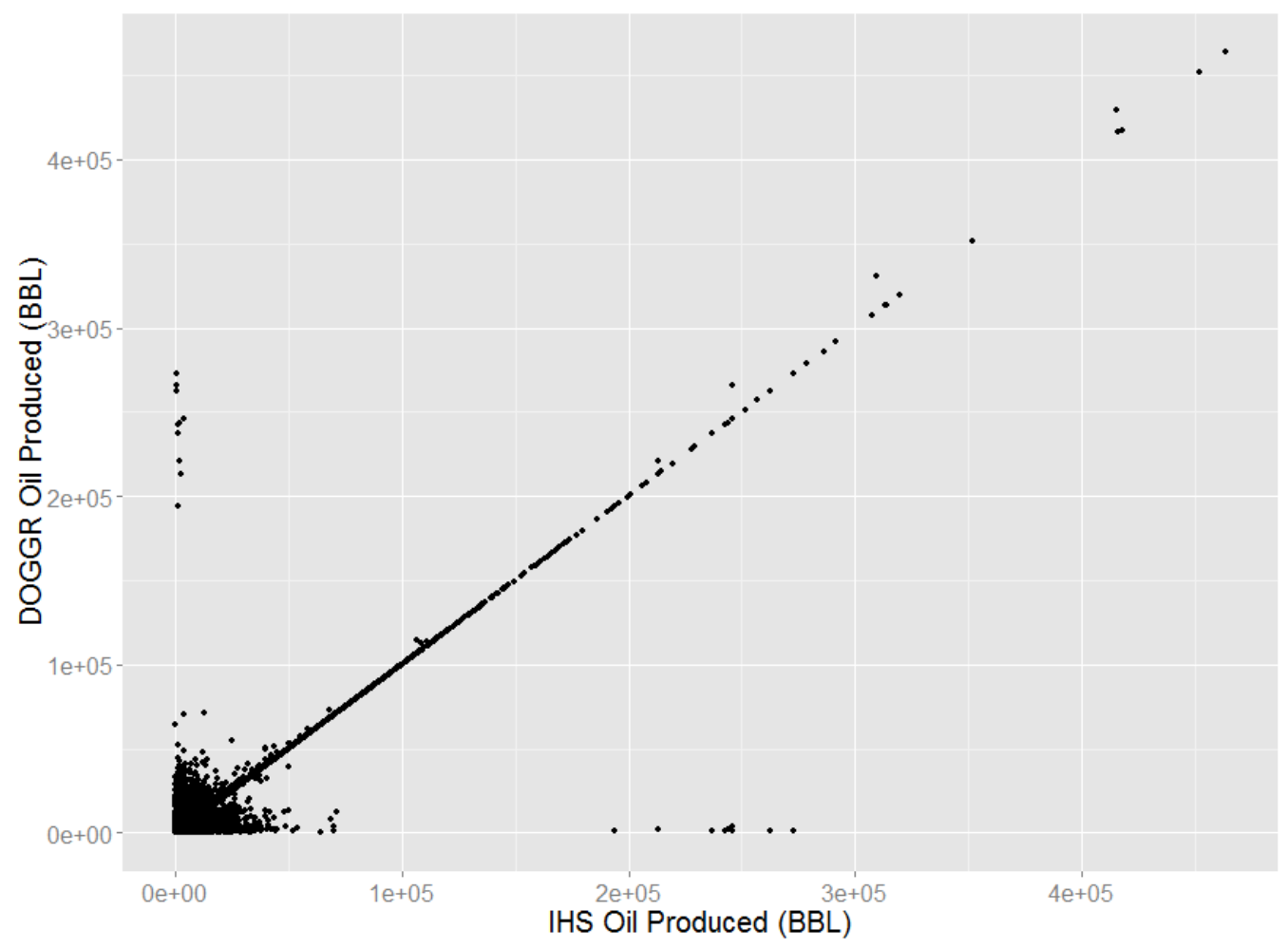

Figure S9. Comparison of oil volumes produced (BBL) reported by DOGGR and IHS databases.

\section{Units and Conversions}

Units:

MMbbl = million barrels (oil)

$\mathrm{Mcf}=$ thousand cubic feet

Conversions:

Energy content of crude $=6.119 \mathrm{GJ} / \mathrm{L}$ based on $5.8 \times 10^{6}$ Btu per barrel of oil (LHV). ${ }^{18}$ Energy content of gas $=1.023 \times 10^{6}$ Btu per Mcf. ${ }^{18}$

1 oil barrel $=159$ Liters (42 US gallons)

1 oil barrel equivalent = GJ natural gas x $(1$ L/6.119 GJ) $\times(1$ barrel/159 L) 


\section{References}

1. U.S. Energy Information Administration, Crude Oil Production. In Administration, U. S. E. I., Ed. 2014.

2. California Division of Oil Gas and Geothermal Resources California Class II Underground Injection Control Program Review Final Report; 2011.

3. California Division of Oil Gas and Geothermal Resources California Laws for Conservation of Petroleum and Gas; California Division of Oil, Gas, and Geothermal Resources, 2014.

4. U.S. Energy Information Administration, Natural Gas Gross Withdrawals and Production: Vented and Flared. In Energy Information Administration, 2014.

5. Brandt, A. R.; Unnasch, S., Energy Intensity and Greenhouse Gas Emissions from Thermal Enhanced Oil Recovery. Energy \& Fuels 2010, 24, (8), 4581-4589.

6. California Division of Oil Gas and Geothermal Resources 2009 Annual Report of the State Oil and Gas Supervisor; California Department of Conservation, Division of Oil Gas and Geothermal Resources.: 2009.

7. Macknick, J.; Newmark, R.; Heath, G.; Hallett, K., A review of operational water consumption and withdrawal factors for electricity generating technologies. Contract 2011, 303, 275-300.

8. Gleick, P. H., Water and Energy. Annual Review of Energy and the Environment 1994, 19, (1), 267-299.

9. Wu, M.; Mintz, M.; Wang, M.; Arora, S., Water consumption in the production of ethanol and petroleum gasoline. Environmental Management 2009, 44, (5), 981-97.

10. King, C. W.; Webber, M. E., Water intensity of transportation. Environmental Science \& Technology 2008, 42, (21), 7866-7872.

11. Bush, J.; Helander, D., Empirical Prediction of Recovery Rate in the Waterflooding of Depleted Sands. Pres. at the North Texas 8th Biennial Secondary Recovery Symp., Wichita Falls, Tex., May 6-7. SPE Preprint Paper 1968, (2109), 18.

12. Donaldson, E. C.; Chilingarian, G. V.; Yen, T. F., Enhanced oil recovery II. Elsevier Science: 1989.

13. Royce, B.; Kaplan, E.; Garrell, M.; Geffen, T. M., Enhanced oil recovery water requirements. Minerals and the Environment 1984, 6, (2), 44-53.

14. Scown, C. D.; Horvath, A.; McKone, T. E., Water Footprint of U.S. Transportation Fuels. Environmental Science \& Technology 2011, 45, (7), 2541-2553.

15. Kovscek, A. R., Emerging challenges and potential futures for thermally enhanced oil recovery. Journal of Petroleum Science and Engineering 2012, 98-99, (0), 130-143.

16. U.S. Environmental Protection Agency. "Methanol". http://www.epa.gov/ttn/atw/hlthef/methanol.html

17. Colborn, T.; Kwiatkowski, C.; Schultz, K.; Bachran, M., Natural gas operations from a public health perspective. Human and Ecological Risk Assessment: An International Journal 2011, 17, (5), 1039-1056.

18. U.S. Energy Information Administration Annual Energy Review. Appendix A: British Thermal Unit Conversion Factors; United States Energy Information Administration 2011. 